\title{
Evaluation of the interaction between polymyxin B and Pseudomonas aeruginosa biofilm and planktonic cells: reactive oxygen species induction and zeta potential
}

Marlucy Rodrigues Lima ${ }^{1+}$, Gabriella Freitas Ferreira $2^{2^{*}}$ (D), Wallace Ribeiro Nunes Neto ${ }^{3}$, Joveliane de Melo Monteiro ${ }^{3}$, Áquila Rodrigues Costa Santos ${ }^{2}$, Priscila Batista Tavares ${ }^{1}$, Ângelo Márcio Leite Denadai ${ }^{2}$, Maria Rosa Quaresma Bomfim³ ${ }^{3}$, Vera Lúcia dos Santos ${ }^{4}$, Sirlei Garcia Marques ${ }^{5,6}$ and Andrea de Souza Monteiro ${ }^{3}$

\begin{abstract}
Background: Although the most widely accepted mechanism of action for polymyxins is related to bacterial lysis via disruption, we hypothesized that this antimicrobial drug class could have other effects on Pseudomonas aeruginosa planktonic and sessile cells. Little is known regarding oxidative burst and zeta potential (ZP) data associated with the interaction between polymyxin B and $P$. aeruginosa cells. The present study evaluated endogenous reactive oxygen species (ROS) production and changes in the net charges of biofilm and planktonic cells in response to polymyxin $B$.
\end{abstract}

Results: Polymyxin B induced concentration-dependent killing at all concentrations tested in planktonic and sessile cells from $P$. aeruginosa strains. Sublethal concentrations of polymyxin B induced oxidative burst. ROS production was higher in resistant planktonic cells than in biofilm cells but this was not observed for susceptible cells. Moreover, no net surface charge alterations were observed in planktonic cells from a susceptible strain treated with polymyxin B, but a significant increase of ZP was noted in planktonic cells from a resistant strain.

Conclusion: Oxidative burst generated by planktonic and sessile cells from $P$. aeruginosa strains against polymyxin $\mathrm{B}$ indicates that ROS may have an important role in the mechanism of action of this drug. ZP data revealed that electrostatic interactions of the cationic peptide with the anionic surface of the cells are strain-dependent. Therefore, we suggested that the intracellular effects of polymyxin B should be further investigated to understand polymyxin B-induced stress in $P$. aeruginosa.

Keywords: P. aeruginosa, Biofilm and planktonic cells, Polymyxin B, Reactive oxygen species, Surface electrical property

\footnotetext{
* Correspondence: gabriella.freitas@ufjf.edu.br

${ }^{+}$Marlucy Rodrigues Lima and Gabriella Freitas Ferreira contributed equally to this work.

²Departamento de Farmácia, Programa Multicêntrico de Pós-Graduação em Bioquímica e Biologia Molecular, Universidade Federal de Juiz de Fora, UFJF, Campus Governador Valadares - MG. R. Manoel Byrro, 241 - Vila Bretas, Governador Valadares, MG 35032-620, Brazil

Full list of author information is available at the end of the article
}

(c) The Author(s). 2019 Open Access This article is distributed under the terms of the Creative Commons Attribution 4.0 International License (http://creativecommons.org/licenses/by/4.0/), which permits unrestricted use, distribution, and reproduction in any medium, provided you give appropriate credit to the original author(s) and the source, provide a link to the Creative Commons license, and indicate if changes were made. The Creative Commons Public Domain Dedication waiver (http://creativecommons.org/publicdomain/zero/1.0/) applies to the data made available in this article, unless otherwise stated. 


\section{Background}

Pseudomonas aeruginosa is one of the most important pathogenic bacteria species in the context of hospital infections [1]. It causes high mortality rates in immunocompromised patients, and it is currently classified as a "superbug" because of the limited effectiveness of antimicrobial drugs [2].

The emergence of $P$. aeruginosa with resistance to $\beta$-lactam antibiotics, including carbapenems, has resulted in few effective treatments for patients with serious infections [3-6]. Over the past 20 years, polymyxins have been reintroduced for the treatment of infections caused by gram-negative bacteria such as $P$. aeruginosa with multi-drug-resistant phenotypes, including resistance to carbapenems and quinolones [7].

Polymyxin B is a cationic antimicrobial cationic peptide that increases cell membrane permeability. The most widely accepted mechanism of action for polymyxins is the interaction with lipopolysaccharide (LPS) in the outer membrane of gram-negative bacteria, disrupting cellular osmotic balance [7] Thus, we hypothesized that polymyxins could have other effects on planktonic and sessile gram-negative bacteria. Little is known regarding the physicochemical effects of polymyxin $\mathrm{B}$ on $P$. aeruginosa biofilms, including the zeta potential (ZP). Electrostatic interactions have been observed between cationic agents and Klebsiella pneumoniae, Acinetobacter baumannii, Staphylococcus aureus, and Escherichia coli [8-10], and it was suggested that these interactions interfere with cellular net charges and consequently alter cell surface permeability, leading to cell death.

There is also a gap in knowledge regarding polymyxin $\mathrm{B}$-induced endogenous reactive oxygen species (ROS) production in planktonic and sessile $P$. aeruginosa cells. For ciprofloxacin, the formation of hydroxyl radicals $\left({ }^{\circ} \mathrm{OH}\right)$ in planktonic cells and biofilm-grown P. aeruginosa contributes to the mechanism of bactericide [11]. Sampson and colleagues observed that the rapid production of hydroxyl radicals caused by polymyxins is involved in A. baumannii, E. coli, and Francisella novicida planktonic cell death [12]. Conversely, some studies demonstrated that the bactericidal activity of colistin on planktonic and biofilm $P$. aeruginosa cells is independent of ${ }^{\circ} \mathrm{OH}$ formation $[13,14]$. Although these studies have produced conflicting results, various cell pathways have been proposed to be responsible for the generation of ROS triggered by the exposure of $E$. coli to antibiotics [15]. ROS increased the frequency of mutation rates in gyrA and $\operatorname{gyr} B$ in bacterial cells exposed to ampicillin, contributing to a norfloxacin-resistant phenotype [15]. ROS generation in $E$. coli associated with antibiotic exposure may also be caused by changes in redox complexes that contribute to cell damage and death because of the alterations to central metabolism, cellular respiration, and iron metabolism [16].

Thus, we evaluated ROS production in biofilm-derived and planktonic $P$. aeruginosa cells in response to polymyxin $B$ and investigated differences in bacterial surface charges caused by polymyxin $\mathrm{B}$ as measured by zeta potential.

\section{Results}

Minimal inhibitory concentration (MIC), minimum biofilm eliminating concentration (MBEC), and time-kill curve assays for planktonic and biofilm cells

The MIC and MBEC for polymyxin B against $P$. aeruginosa $\mathrm{P} 1 \mathrm{C}$ were 0.5 and $128 \mathrm{mg} / \mathrm{L}$, respectively. For the P9C strain, these values were 64 and $512 \mathrm{mg} / \mathrm{L}$, respectively. Because of the MIC, the P1C strain was classified as susceptible to polymyxin B, whereas the P9C strain was considered resistant [17].

To evaluate the kinetics of the action of polymyxin $B$ against planktonic and sessile cells, time-kill curves were generated at different times and concentrations using two $P$. aeruginosa strains. For planktonic cells from the susceptible strain, polymyxin B provided a bacteriostatic curve at $0.5 \mathrm{mg} / \mathrm{L}$ (MIC), with $50 \%$ growth inhibition after $24 \mathrm{~h}$ of treatment (Fig. 1a). At concentrations of 1 $\mathrm{mg} / \mathrm{L}(2 \times \mathrm{MIC})$ and $2 \mathrm{mg} / \mathrm{L}(4 \times \mathrm{MIC})$, polymyxin $\mathrm{B}$ induced a concentration-dependent killing of susceptible $P$. aeruginosa planktonic cells, with $100 \%$ growth inhibition after $18 \mathrm{~h}$ of treatment at $2 \times \mathrm{MIC}$ and after $6 \mathrm{~h}$ of treatment at $4 \times$ MIC (Fig. 1a). Same profile was observed for resistant strain (Fig. 1c): bacteriostatic curve at $64 \mathrm{mg} / \mathrm{L}$ (MIC) and bactericidal curve at $128(2 \times \mathrm{MIC})$ and 256 $\mathrm{mg} / \mathrm{L}(4 \times \mathrm{MIC})$. Conversely, polymyxin $\mathrm{B}$ induced concentration-dependent killing at all concentrations tested in sessile cells from both strains (Fig. 1b and d).

\section{ROS production}

Polymyxin B significantly induced ROS production after $3 \mathrm{~h}$ of treatment in planktonic (P1C: untreated, 28.20 \pm 1.44 AU; treated, $40.07 \pm 1.61 \mathrm{AU} ; \mathrm{P} 9 \mathrm{C}$ strain: untreated, $37.38 \pm 1.23 \mathrm{AU}$; treated, $115.00 \pm 2.56 \mathrm{AU}$ ) and sessile cells compared with the findings for the growth control (P1C: untreated, $36.36 \pm 3.13 \mathrm{AU}$; treated, 87.24 \pm 4.47 AU; P9C strain: untreated, $21.24 \pm 2.13 \mathrm{AU}$; treated, $97.61 \pm 1.50 \mathrm{AU})(\mathrm{P}<0.05)$ (Fig. $2 \mathrm{a}$ and $\mathrm{b})$.

The results illustrated that ROS production was higher in resistant planktonic cells than in biofilm cells $(\mathrm{P}<$ 0.05) (Fig. 2b), but this was not observed for susceptible cells (Fig. 2a).

\section{Effect of polymyxin B on $P$. aeruginosa cell surface zeta potential (ZP)}

For planktonic cells from susceptible strains, $0.25(0.5 \times$ $\mathrm{MIC}), 0.5$ (MIC), 1 (2× MIC) and $2 \mathrm{mg} / \mathrm{L}(4 \times \mathrm{MIC})$ polymyxin $\mathrm{B}$ did not change the electrical charges of 


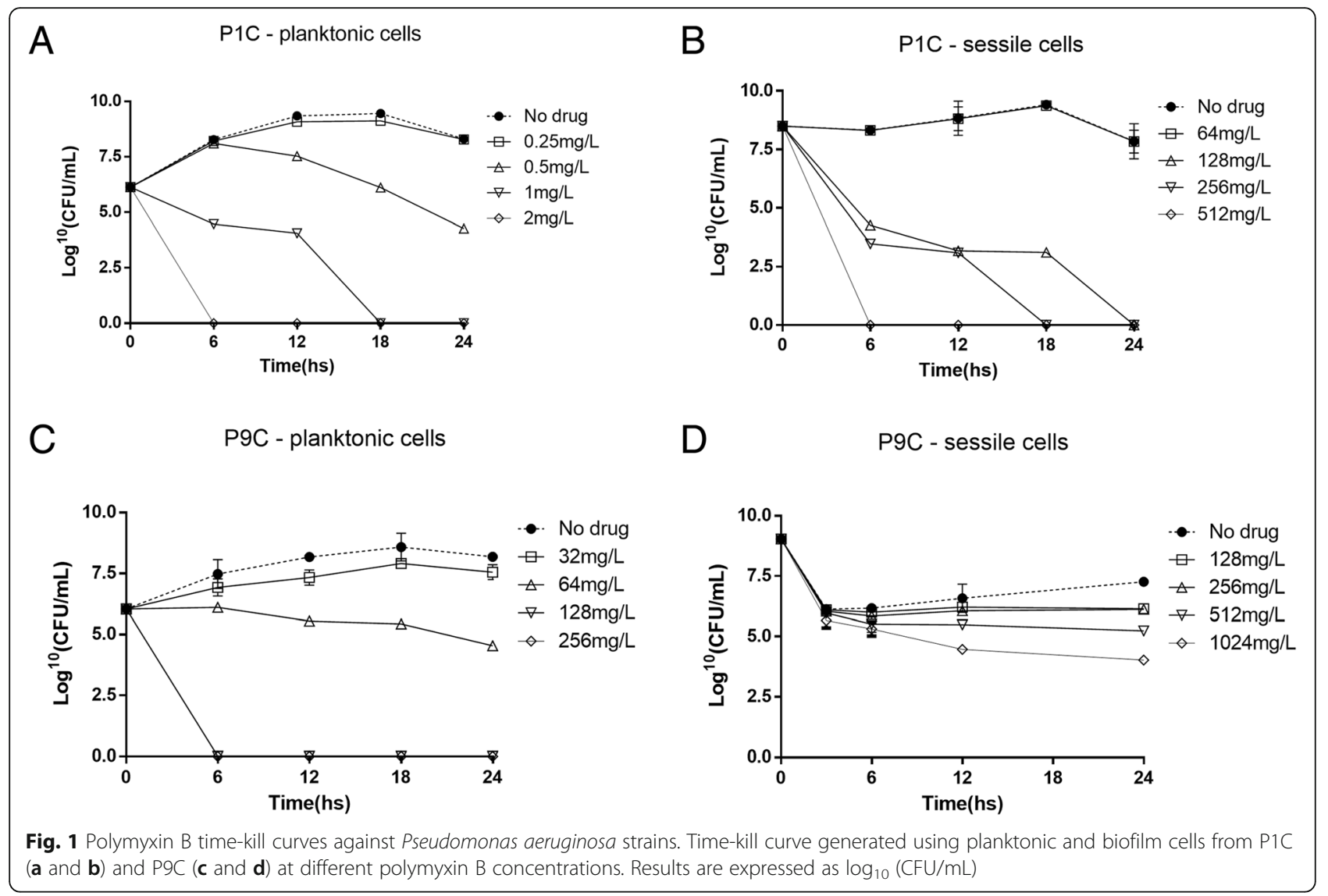

surface cells (untreated, $-14.96 \pm 1.11 \mathrm{z} / \mathrm{mV} ; 0.25 \mathrm{mg} / \mathrm{L}$, $-13.68 \pm 0.53 \mathrm{z} / \mathrm{mV} ; 0.5 \mathrm{mg} / \mathrm{L}, \quad-14.18 \pm 0.76 \mathrm{z} / \mathrm{mV} ; 1$ $\mathrm{mg} / \mathrm{L},-13.38 \pm 0.65 \mathrm{z} / \mathrm{mV} ; 2 \mathrm{mg} / \mathrm{L}:-13.95 \pm 0.94 \mathrm{z} / \mathrm{mV})$ (Fig. 3a). Conversely, for sessile cells, 256 (2× MBEC) and $512 \mathrm{mg} / \mathrm{L}(4 \times \mathrm{MBEC})$ polymyxin $\mathrm{B}$ modified the net charges of their surfaces (untreated, $-11.70 \pm 0.48 \mathrm{z} / \mathrm{mV}$; $128 \mathrm{mg} / \mathrm{L},-11.11 \pm 0.45 \mathrm{z} / \mathrm{mV} ; 256 \mathrm{mg} / \mathrm{L},-11.17 \pm 0.67$ $\mathrm{z} / \mathrm{mV} ; \quad 512 \mathrm{mg} / \mathrm{L}, \quad-9.33 \pm 0.30 \mathrm{z} / \mathrm{mV} ; \quad 1024 \mathrm{mg} / \mathrm{L}, \quad-$ $10.24 \pm 0.30 \mathrm{z} / \mathrm{mV}$ ) (Fig. 3b).

We observed that the electrical charges of the surfaces of resistant planktonic cells were modified significantly following exposure to all polymyxin $\mathrm{B}$ concentrations tested (untreated, $-14.45 \pm 0.17 \mathrm{z} / \mathrm{mV} ; 32 \mathrm{mg} / \mathrm{L},-9.45 \pm$ $0.61 \mathrm{z} / \mathrm{mV} ; 64 \mathrm{mg} / \mathrm{L},-9.08 \pm 0.32 \mathrm{z} / \mathrm{mV} ; 128 \mathrm{mg} / \mathrm{L},-8.79$ $\pm 0.50 \mathrm{z} / \mathrm{mV} ; 256 \mathrm{mg} / \mathrm{L},-9.12 \pm 0.37 \mathrm{z} / \mathrm{mV})(\mathrm{P}<0.05)$ (Fig. 3c). However, alterations of ZP were observed in cells detached from the biofilm and treated with polymyxin $B$ only at a concentration of $1024 \mathrm{mg} / \mathrm{L}$ ( $4 \times \mathrm{MIC}$ ) (untreated, $-12.63 \pm 0.48 \mathrm{z} / \mathrm{mV} ; 128 \mathrm{mg} / \mathrm{L},-14.48 \pm 0.47 \mathrm{z} /$ $\mathrm{mV} ; 256 \mathrm{mg} / \mathrm{L},-13.03 \pm 0.77 \mathrm{z} / \mathrm{mV} ; 512 \mathrm{mg} / \mathrm{L},-9.81 \pm$ $0.56 \mathrm{z} / \mathrm{mV} ; 1024 \mathrm{mg} / \mathrm{L},-7.25 \pm 0.59 \mathrm{z} / \mathrm{mV}$ ) (Fig. 3d).

\section{Discussion}

Antimicrobial resistance in $P$. aeruginosa, as indicated by biofilm formation, is recognized as a major cause of therapeutic failure for chronic lung infection in patients with cystic fibrosis [18, 19]. Polymyxin B is increasingly used clinically as the last therapeutic option for multidrug-resistant gram-negative bacterial infections $[20,21]$. Consequently, more studies are been conducted to understand the effect of polymyxins on $P$. aeruginosa.

As expected, biofilm cells were more resistant to polymyxin B than planktonic cells. Usually, mature biofilm expresses an extracellular matrix that functions as a protective barrier against antibiotic permeation [22]. This is partially caused by metabolic changes resulting from the limited oxygen availability and nutrient penetration through the biofilm because of bacterial consumption.

Only a small number of in vitro time-kill studies on polymyxins against $P$. aeruginosa strains have been conducted. To the best of our knowledge, this is the first study examining the pharmacodynamics of polymyxin $B$ in sessile cells from $P$. aeruginosa. Our results demonstrated that the bactericidal activity of polymyxin B was concentration-dependent, corroborating other studies $[20,23]$. Significant declines (>2-log decrease) in the bacterial burden were observed after $24 \mathrm{~h}$ after MIC and MBEC for both strains. With increasing polymyxin $\mathrm{B}$ concentrations, a higher killing rate and a greater extent 

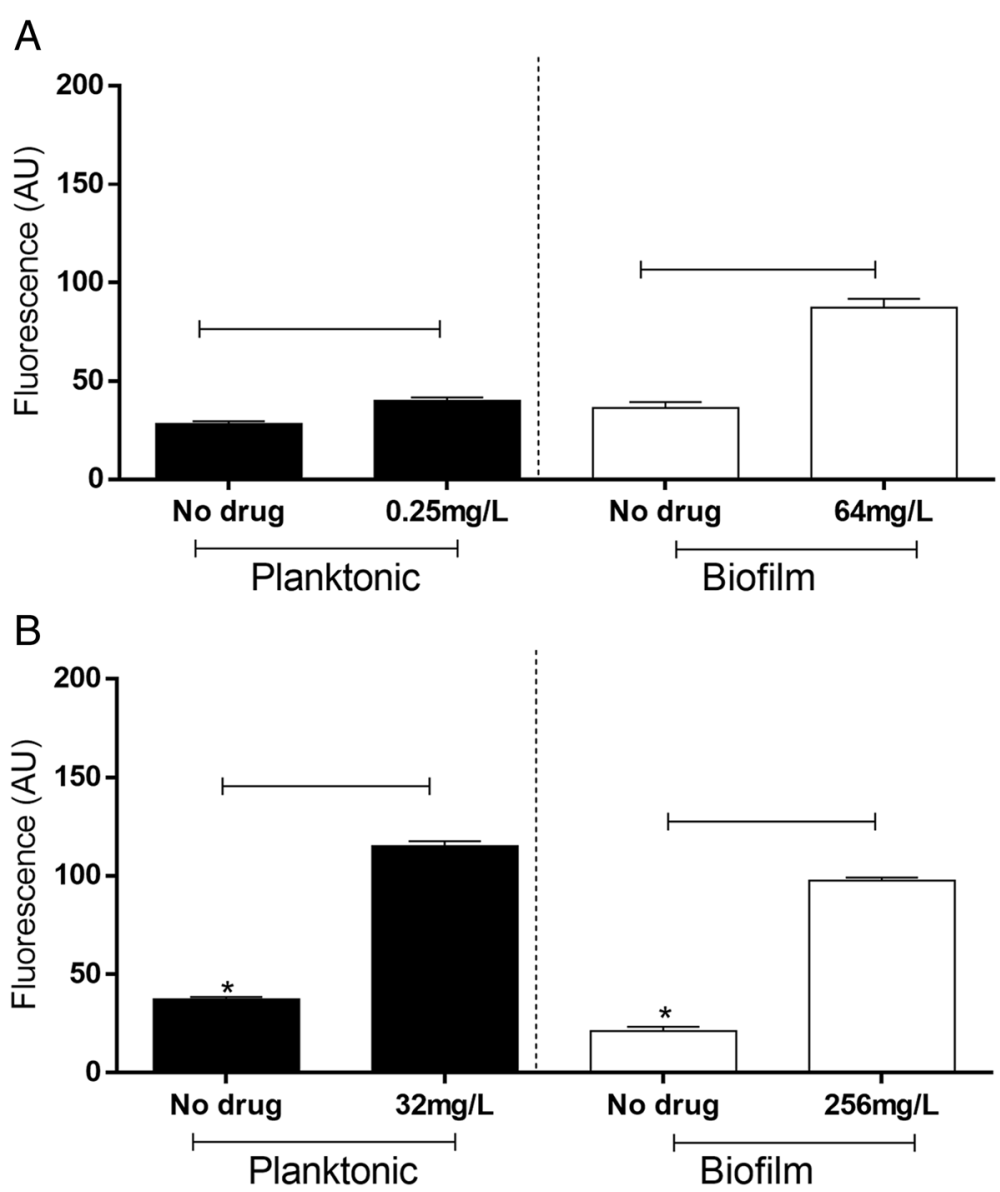

Fig. 2 Quantities of reactive oxygen species (ROS) in Pseudomonas aeruginosa P1C (a) and P9C (b) cells in the presence of polymyxin B. ROS were quantified at $37^{\circ} \mathrm{C}$ after $3 \mathrm{~h}$ of incubation. The groups contained untreated and treated cells with $0.5 \times$ minimum inhibitory concentration of polymyxin B and 1\% hydrogen peroxide (data no shown). Results are expressed in arbitrary units of fluorescence. Each data point represents the mean of three independent samples. Significant differences between the treated and untreated cells are represented by connected lines $(P<$ 0.05), and those between planktonic and biofilm cells are represented by asterisks $(P<0.05)$. Data are presented as the mean \pm S.E. of two independent experiments

of killing were observed in both strains for planktonic and sessile cells (Fig. 1).

Studies have illustrated that some antibiotics promote oxidative burst in microorganisms, but their main mechanisms of action are not related with reactive species [15, 24-26]. The role of oxidative burst in the effects of polymyxin against $P$. aeruginosa is not clear. Some studies reported that the bactericidal activity of colistin in $P$. aeruginosa is independent of hydroxyl radical formation [14], and the effect was increased in biofilms under anaerobic conditions [13]. However, other studies demonstrated that bacterial respiration can be inhibited by polymyxins because of cytoplasmic membrane disruption in $P$. aeruginosa cells, allowing the accumulation of toxic intermediates [27-29]. Our results corroborate the hypothesis that treatment of $P$. aeruginosa cells with polymyxin B results in increased ROS levels (Fig. 2). It has been proposed that polymyxin initially accumulates in the outer membrane and subsequently penetrates the inner membrane to enter the cytoplasm [30], leading to reactive species production [31, 32] via inhibition of NADH-quinone oxidoreductase activity [29]. The free radicals accumulate and damage DNA, lipids, and proteins, eventually causing cell death [16].

The production of ROS was higher in planktonic cells than biofilm cells for the resistant strain (Fig. 2b) regardless of treatment with polymyxin B. However, this was not true for the susceptible strain (Fig. 2a). The intrinsic oxidative burst and activity of antioxidant cell system may be strain-dependent [33]. Based on our results, we can hypothesize that sessile cells from the P9C strain is better adapted to oxidative stress than planktonic cells, which may explain the lower damage caused by polymyxin B-induced stress.

It is unclear in the literature whether polymyxin B can change the net charges of planktonic and sessile surface 


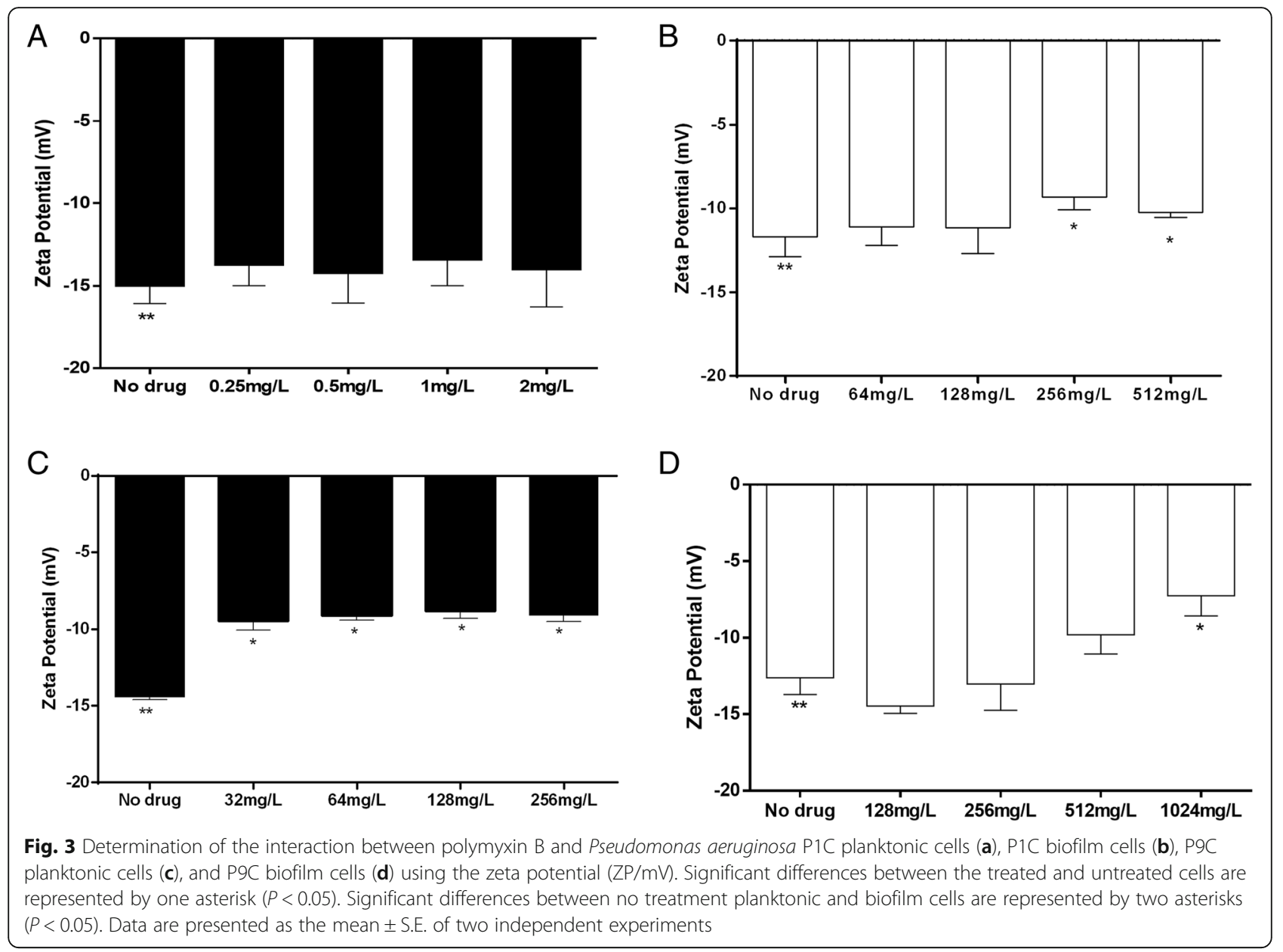

cells. It has been suggested that alteration of ZP may be correlated with the enhancement of membrane permeability [9]. We observed that electrical charges of the surfaces of resistant planktonic cells were modified following exposure to all concentrations of polymyxin B tested (Fig. 3c), but no alterations of ZP were found in planktonic cells from the susceptible strain (Fig. 3a). The net surface charge must change during ionic interactions, as shown by the ZP measurements. We believed that cell death caused by polymyxin $\mathrm{B}$ in the $P$. aeruginosa $\mathrm{P} 1 \mathrm{C}$ susceptible strain is principally mediated by anionic intracellular target(s) of the polymyxins, probably through oxidative burst, but more studies needed to confirm this hypothesis. Prior research demonstrated that polymyxin-mediated cell death can occur prior to cytoplasmic membrane depolarization, and the interaction with membranes may not the only lethal event $[30,34]$. Consequently, we believe that for resistant $P$. aeruginosa $\mathrm{P} 9 \mathrm{C}$, the interaction of polymyxin $\mathrm{B}$ with LPS in the outer membrane limited the penetration of this drug into the cytoplasm, diminishing the antimicrobial effect of polymyxin B. Corroborating this hypothesis, a prior study reported that a polymyxin-resistant strain selected from the reference $K$. pneumoniae strain in the presence of colistin had a less negative and more permeable outer membrane than the wild-type strain [8]. In this case, the increased membrane fluidity did not coincide with polymyxin susceptibility $[8,34,35]$.

Cells detached from biofilms (Fig. 3b and d) from both strains had less negative charges than their respective planktonic cells (Figs. 3a and c). Previous studies demonstrated that a strategy used by bacteria to adapt to polymyxin B-mediated stress involves conversion of the surface charge to a more positive value through LPS modifications. These changes reduce or prevent the initial interaction between the antibiotic and LPS, resulting in resistance [26]. Some bacterial species have evolved different mechanisms to modify lipid A, thereby reducing the net negative cell surface charge. The principal modification consists of the insertion of 4-amino-4-deoxy-L-arabinose and/or phosphoethanolamine in the phosphate groups of the molecule [36-38]. It was observed that the net cell charge is influenced by the cell growth phase [8], and thus, we supposed that phenotypic modifications of planktonic and sessile cells are responsible for our data. Clearly, the relationship between polymyxin resistance and ZP is extremely complex. 
We observed that a higher concentration of polymyxin $B$ is required to overcome the extracellular matrix of the biofilm and promote changes of the net charges of cells (Fig. $3 \mathrm{~b}$ and $\mathrm{d}$ ). In addition, once the extracellular matrix is formed, it can form electrostatic interactions (repulsion and sequestration molecules) with polymyxin B, decreasing the amount of free drug interacting with the surface of gram-negative bacteria $[39,40]$.

\section{Conclusions}

Oxidative burst generated by $P$. aeruginosa cells in response to polymyxin B may have an important role in mechanism of action of this drug. The zeta potential data revealed that the electrostatic interactions of polymyxin B with the cell surface are strain-dependent, and they could be related to the mechanism of cell killing, which is probably attributable to extracellular and intracellular processes.

\section{Methods}

\section{Antimicrobial drug susceptibility testing and time-kill} curves for planktonic cells

In this study, tests were performed using the clinical $P$. aeruginosa strains $\mathrm{P} 1 \mathrm{C}$ and $\mathrm{P} 9 \mathrm{C}$ obtained from the culture collection of the Applied Microbiology Laboratory of the University CEUMA (Maranhão, São Luís, MA, Brazil). P. aeruginosa $\mathrm{P} 1 \mathrm{C}$ and $\mathrm{P} 9 \mathrm{C}$ strains were isolated from blood culture samples and identified via MALDI-QTOF-mass spectrometry (Biotyper system, Bruker, Billerica, MA, USA) in the Cedro Laboratory (Maranhão, São Luís, MA, Brazil). In addition, P1C was susceptible to polymyxin B, cefepime, and ceftazidime; indifferent to ciprofloxacin; and resistant to levofloxacin. $P$. aeruginosa The P9C strain was resistant to norfloxacin, ciprofloxacin, meropenem, ampicillin, and polymyxin B and was chosen for the study among 40 total tested isolates because of its excellent biofilm formation pattern in vitro (data not shown). The P9C strain was maintained on slants of brain heart infusion agar (BHIA; Difco Laboratories, Detroit, MI, USA) at $4{ }^{\circ} \mathrm{C}$. Prior to each test, the strain was subcultured on BHIA for $24 \mathrm{~h}$ at $35^{\circ} \mathrm{C}$.

The MIC of polymyxin B in planktonic cells was determined using the broth microdilution method as described in CLSI M07-A10 [17]. For this purpose, different concentrations of polymyxin B (0.125-512 mg/ L) were incubated with $100 \mu \mathrm{L}$ of cation-adjusted Mueller-Hinton broth (Difco) supplemented to give final concentrations of calcium $20-25 \mathrm{mg} / \mathrm{mL}$ and magnesium $10-12.5 \mathrm{mg} / \mathrm{L}$ in 96 -well plates. The bacterial inoculum was prepared in $0.9 \% \mathrm{NaCl}$ (sterile saline), and transmittance of the suspensions was adjusted to 75$77 \% \quad(530 \mathrm{~nm})$, followed by further dilution in cation-adjusted Mueller-Hinton broth to achieve a concentration of $5.0 \times 10^{5} \mathrm{CFU} / \mathrm{mL}$ in the well. Negative (no bacteria) and growth (no drug) controls were included for each assay. The plates were incubated under aerobic conditions at $35^{\circ} \mathrm{C}$ for $24 \mathrm{~h}$. The MIC endpoint for interpreting the results was determined visually as $100 \%$ reduction of growth in the presence of polymyxin B compared with the control growth. The results were confirmed by adding the salt 3-(4,5-dimethylthiazo1-2-yl)-2,5-diphenyltetrazolium bromide (1.0 g/L, MTT, Sigma-Aldrich) to determine the reduction of the cell metabolic activity as described previously. All the tests were performed in triplicate.

The time-kill curve assays for planktonic cells were performed as described previously [41] with modifications. Bacterial inoculum prepared to achieve a final concentration of $5.0 \times 10^{5} \mathrm{CFU} / \mathrm{mL}$ were treated with polymyxin $\mathrm{B}$ were prepared cation-adjusted Mueller-Hinton broth and added to the wells.

A $50-\mu \mathrm{L}$ aliquot of bacterial inoculum was removed from the microtiter plates containing polymyxin $\mathrm{B}$ at different intervals until $24 \mathrm{~h}$ and serially diluted in sterile saline $(\mathrm{NaCl}$, 0.9\%), before plating on Pseudomonas agar plates (Difco, Kansas City, MO, USA) for colony count determinations. The plates were incubated at $35^{\circ} \mathrm{C}$ for $24 \mathrm{~h}$ prior to colony counting. The data are presented as the means of three independent experiments in duplicate assays.

\section{MBEC assay and time-kill curve assay for biofilm cells}

Biofilms were formed overnight at $37^{\circ} \mathrm{C}$ in non-treated 96-well polystyrene plates. Bacterial concentrations were prepared as described previously [42]. Next, biofilms were washed three times and exposed to $200 \mu \mathrm{L}$ of polymyxin B was diluted in cation-adjusted Mueller-Hinton broth to concentrations of $0.125-512 \mathrm{mg} / \mathrm{L}$. Plates were incubated overnight at $37^{\circ} \mathrm{C}$. MTT salt $(1.0 \mathrm{~g} / \mathrm{L})$ was used to assess anti-biofilm activity after overnight incubation at $37^{\circ} \mathrm{C}$ (as described previously) [47]. The lowest concentration at which MTT was not converted to formazan was considered the MBEC. This experiment was performed in triplicate.

For the time-kill curve assay for biofilm cells, biofilms were washed three times and exposed to polymyxin B diluted in cation-adjusted Mueller-Hinton broth. The plates were incubated at $37^{\circ} \mathrm{C}$ until $24 \mathrm{~h}$ and serially diluted in sterile saline $(\mathrm{NaCl}, 0.9 \%)$, before plating on Pseudomonas agar plates (Difco, Kansas City, MO, USA) for colony count determinations. The plates were incubated at $35^{\circ} \mathrm{C}$ for $24 \mathrm{~h}$ prior to colony counting. The data are presented as the means of three independent experiments in duplicate assays.

\section{Measurement of ROS production}

Endogenous ROS were measured using a fluorometric assay as described previously with modifications [25, 43]. 
Planktonic or biofilm cells $\left(1.0 \times 10^{7} \mathrm{CFU} / \mathrm{mL}\right)$ were treated with polymyxin B (planktonic, $0.5 \times$ MIC; biofilm, $0.5 \times \mathrm{MBEC}$ ) or hydrogen peroxide ( $1 \%$ positive control) in a buffered mineral medium (in g/L: $1.5 \mathrm{~K}_{2} \mathrm{HPO}_{4}, 0.5$ $\mathrm{KH}_{2} \mathrm{PO}_{4}, 0.5 \mathrm{NaCl}, 0.5 \quad \mathrm{MgSO}_{4} \cdot 7 \mathrm{H}_{2} \mathrm{O}, 3.0 \quad \mathrm{NH}_{4} \mathrm{NO}_{3}$, $0.002 \mathrm{FeSO}_{4} \cdot 7 \mathrm{H}_{2} \mathrm{O}, 0.002 \mathrm{CaCl}_{2} \cdot 2 \mathrm{H}_{2} \mathrm{O}, 0.2$ yeast extract, and $5 \%$ glucose; $\mathrm{pH} 7$ ) and incubated with $10 \mu \mathrm{M}$ $2^{\prime}, 7^{\prime}$-dichlorofluorescin diacetate (Invitrogen, Life Technologies, Carlsbad, CA, USA) at $37^{\circ} \mathrm{C}$. After $3 \mathrm{~h}$ of incubation, fluorescence was measured using a Varioskan ${ }^{\mathrm{m}}$ LUX multimode microplate reader (Thermo Fisher Scientific Inc., Waltham, MA, USA) using excitation and emission wavelengths of 485 and $535 \mathrm{~nm}$, respectively. Data were expressed as arbitrary units of fluorescence \pm standard error of two independent experiments. Cells incubated in the absence of polymyxin B were used as controls.

Statistical analyses were performed using GraphPad Prism ver. 5.00 for Windows (GraphPad Software, San Diego, CA, USA). The Kruskal-Wallis statistical analysis was used to compare differences among groups, followed by Dunn's multiple comparison post-test to detect specific differences. $P<0.05$ was considered significant.

\section{Effect of polymyxin B on zeta potential (ZP)}

Planktonic and biofilm cells were used in the assays. The method used was described previously with modifications [44]. After careful washing of the biofilms with sterile $0.9 \% \mathrm{NaCl}$, the cells were detached, suspended in $5 \mathrm{~mL}$ of $0.9 \% \mathrm{NaCl}$, and vortexed until visual observation of the complete dissolution of the lumps. These suspensions were centrifuged $(4000 \times g$ for $10 \mathrm{~min})$, and the resulting cell pellet was resuspended in $2 \mathrm{~mL}$ of $0.9 \%$ $\mathrm{NaCl}$ for optical density determination using a spectrophotometer. To obtain planktonic cell suspensions, the bacteria were grown in brain heart infusion broth and washed with sterile $0.9 \% \mathrm{NaCl}$. The assay included titration of four manual injections with aqueous polymyxin $\mathrm{B}$ in a glass beaker containing $P$. aeruginosa cell suspensions (planktonic and biofilm cells) at an optical density at $600 \mathrm{~nm}\left(\mathrm{OD}_{600}\right)$ of 0.1 . After each titration, the solution was transferred to a cuvette (Cell-Folded Capillary DTS1060; Malvern Instruments), and the ZP was determined. Data were expressed as $\mathrm{mV} \pm$ standard error of two independent experiments.

The assays for determining ZP were conducted at $25^{\circ}$ $C$ using a Zetasizer NanoZS instrument (Malvern Instruments Inc., Westborough, MA, USA) with 64 channels and a correlator at $633 \mathrm{~nm}$. The technique used for the ZP measurements was in accordance with the Malvern laser Doppler velocimetry patterns coupled with M3-phase analysis light scattering.

Statistical analyses were performed using GraphPad Prism ver. 5.00 for Windows. One-way analysis of variance was used to compare differences among groups, followed by Bonferroni's post-test to detect specific differences. $P<0.05$ was considered significant.

\section{Abbreviations \\ AU: Arbitrary units; CFU: Colony formation unity; CLSI: Clinical and Laboratory Standards Institute; DNA: Deoxyribonucleic acid; LPS: Lipopolysaccharide; MALDI-QTOF: Matrix-assisted laser desorption/ionization; MBEC: Minimum biofilm eliminating concentration; MIC: Minimal inhibitory concentration; MTT: 3-(4,5-dimethylthiazol-2-yl)-2,5-diphenyltetrazolium bromid; $\mathrm{NADH}$ : Nicotinamide adenine dinucleotide; OD: Optical density; $\mathrm{OH}$ : Hydroxyl radicals; ROAS: reactive oxygen species; ZP: Zeta potential}

\section{Acknowledgements}

Not applicable.

\section{Funding}

This study was supported by Conselho Nacional de Desenvolvimento Científico e Tecnológico (CNPq, MCT/CNPq-NANO: 550321/2012-8), Fundação de Amparo à Pesquisa do Estado de Minas Gerais (FAPEMIG, APQ00645-12, APQ-00435-14), and Financiadora de Estudos e Pesquisas (FINEP: 0633/13). The funding bodies have the role of pay the consumption materials used in this work and pay financial aid to students.

\section{Availability of data and materials}

The datasets used and/or analysed during the current study are available from the corresponding author on reasonable request.

\section{Authors' contributions}

M.R.L. - Conception, design, acquisition of data, analysis and interpretation of data of this study; G.F.F. - Conception, design, acquisition of data, analysis and interpretation of data of this study; W.R.N.N. - Acquisition of data of this study; J.M.M. - Acquisition of data of this study; A.R.C.S. - Acquisition of data, analysis and interpretation of data of this study; P.B.T. - Acquisition of data, analysis and interpretation of data of this study; A.M.L.D. - Acquisition of data, analysis and interpretation of data of this study; M.R.Q.B. - Acquisition of data of this study; V.L.S. - Conception, design, acquisition of data, analysis and interpretation of data of this study; drafting and revising of the manuscript; S.G.M. - Acquisition of data of this study; A.S.M. - Conception, design, acquisition of data, analysis and interpretation of data of this study; drafting and revising of the manuscript. All authors read and approved the final version of the manuscript.

Ethics approval and consent to participate Not applicable.

\section{Consent for publication}

Not applicable.

\section{Competing interests}

The authors declare that they have no competing interests.

\section{Publisher's Note}

Springer Nature remains neutral with regard to jurisdictional claims in published maps and institutional affiliations.

\section{Author details}

${ }^{1}$ Faculdade de Ciências da Saúde, Universidade Vale do Rio Doce, Governador Valadares, MG, Brazil. ²Departamento de Farmácia, Programa Multicêntrico de Pós-Graduação em Bioquímica e Biologia Molecular, Universidade Federal de Juiz de Fora, UFJF, Campus Governador Valadares MG. R. Manoel Byrro, 241 - Vila Bretas, Governador Valadares, MG 35032-620, Brazil. ${ }^{3}$ Universidade CEUMA, São Luís, MA, Brazil. ${ }^{4}$ Departamento de Microbiologia, Instituto de Ciência Biológicas, Universidade Federal de Minas Gerais, Belo Horizonte, MG, Brazil. ${ }^{5}$ Hospital Universitário da Universidade Federal do Maranhão, São Luís, MA, Brazil. 'aboratório Cedro, São Luís, MA, Brazil. 
Received: 8 March 2018 Accepted: 10 May 2019 Published online: 29 May 2019

\section{References}

1. Potron A, Poirel L, Nordmann P. Emerging broad-spectrum resistance in Pseudomonas aeruginosa and Acinetobacter baumannii: mechanisms and epidemiology. Int J Antimicrob Agents. 2015;45(6):568-85.

2. Lo Sciuto A, Fernández-Piñar R, Bertuccini L, losi F, Superti F, Imperi F. The periplasmic protein TolB as a potential drug target in Pseudomonas aeruginosa. PLoS One. 2014;9(8):e103784.

3. Villegas MV, Lolans K, Correa A, Kattan JN, Lopez JA, Quinn JP, et al. First identification of Pseudomonas aeruginosa isolates producing a KPC-type carbapenem-hydrolyzing beta-lactamase. Antimicrob Agents Chemother. 2007;51(4):1553-5.

4. Meini MR, Llarrull LI, Vila AJ. Evolution of Metallo- $\beta$-lactamases: trends revealed by natural diversity and in vitro evolution. Antibiotics (Basel). 2014; 3(3):285-316.

5. Struelens MJ, Monnet DL, Magiorakos AP, Santos O'Connor F, Giesecke J, Participants EN-S. New Delhi metallo-beta-lactamase 1-producing Enterobacteriaceae: emergence and response in Europe. Euro Surveill. 2010; (46):15.

6. Poirel L, Hombrouck-Alet C, Freneaux C, Bernabeu S, Nordmann P. Global spread of New Delhi metallo-ß-lactamase 1. Lancet Infect Dis. 2010;10(12): 832.

7. Zavascki AP, Goldani LZ, Li J, Nation RL. Polymyxin B for the treatment of multidrug-resistant pathogens: a critical review. J Antimicrob Chemother. 2007;60(6):1206-15.

8. Velkov T, Deris ZZ, Huang JX, Azad MA, Butler M, Sivanesan S, et al. Surface changes and polymyxin interactions with a resistant strain of Klebsiella pneumoniae. Innate Immun. 2014;20(4):350-63.

9. Halder S, Yadav KK, Sarkar R, Mukherjee S, Saha P, Haldar S, et al. Alteration of zeta potential and membrane permeability in bacteria: a study with cationic agents. Springerplus. 2015;4:672.

10. Soon RL, Nation RL, Cockram S, Moffatt JH, Harper M, Adler B, et al. Different surface charge of colistin-susceptible and -resistant Acinetobacter baumannii cells measured with zeta potential as a function of growth phase and colistin treatment. J Antimicrob Chemother. 2011;66(1):126-33.

11. Jensen P, Briales A, Brochmann RP, Wang H, Kragh KN, Kolpen M, et al. Formation of hydroxyl radicals contributes to the bactericidal activity of ciprofloxacin against Pseudomonas aeruginosa biofilms. Pathog Dis. 2014; 70(3):440-3.

12. Sampson TR, Liu X, Schroeder MR, Kraft CS, Burd EM, Weiss DS. Rapid killing of Acinetobacter baumannii by polymyxins is mediated by a hydroxyl radical death pathway. Antimicrob Agents Chemother. 2012;56(11):5642-9.

13. Kolpen M, Appeldorff CF, Brandt S, Mousavi N, Kragh KN, Aydogan S, et al. Increased bactericidal activity of colistin on Pseudomonas aeruginosa biofilms in anaerobic conditions. Pathog Dis. 2016;74(1):ftv086.

14. Brochmann RP, Toft A, Ciofu O, Briales A, Kolpen M, Hempel C, et al. Bactericidal effect of colistin on planktonic Pseudomonas aeruginosa is independent of hydroxyl radical formation. Int J Antimicrob Agents. 2014; 43(2):140-7.

15. Kohanski MA, DePristo MA, Collins JJ. Sublethal antibiotic treatment leads to multidrug resistance via radical-induced mutagenesis. Mol Cell. 2010;37(3): 311-20.

16. Dwyer DJ, Belenky PA, Yang JH, MacDonald IC, Martell JD, Takahashi N, et al. Antibiotics induce redox-related physiological alterations as part of their lethality. Proc Natl Acad Sci U S A. 2014;111(20):E2100-9.

17. Clinical and Laboratory Standard Institute (CLSI). Performance standards for antimicrobial susceptibility testing. M100-S27th. Clinical and laboratory standards institute, Wayne. In: PA; 2017.

18. Høiby N, Bjarnsholt T, Givskov M, Molin S, Ciofu O. Antibiotic resistance of bacterial biofilms. Int J Antimicrob Agents. 2010;35(4):322-32.

19. Smith WD, Bardin E, Cameron L, Edmondson CL, Farrant KV, Martin I, et al. Current and future therapies for Pseudomonas aeruginosa infection in patients with cystic fibrosis. FEMS Microbiol Lett. 2017;364(14).

20. Tam VH, Schilling AN, Vo G, Kabbara S, Kwa AL, Wiederhold NP, et al. Pharmacodynamics of polymyxin B against Pseudomonas aeruginosa. Antimicrob Agents Chemother. 2005;49(9):3624-30.

21. Diep JK, Jacobs DM, Sharma R, Covelli J, Bowers DR, Russo TA, et al. Polymyxin $B$ in combination with rifampin and Meropenem against
Polymyxin B-resistant KPC-producing Klebsiella pneumoniae. Antimicrob Agents Chemother. 2017;(2):61.

22. Mah TF, O'Toole GA. Mechanisms of biofilm resistance to antimicrobial agents. Trends Microbiol. 2001;9(1):34-9.

23. Bergen PJ, Landersdorfer CB, Zhang J, Zhao M, Lee HJ, Nation RL, et al. Pharmacokinetics and pharmacodynamics of 'old' polymyxins: what is new? Diagn Microbiol Infect Dis. 2012;74(3):213-23.

24. Rosato RR, Fernandez R, Paz LI, Singh CR, Rosato AE. TCA cycle-mediated generation of ROS is a key mediator for HeR-MRSA survival under $\beta$-lactam antibiotic exposure. PLoS One. 2014;9(6):e99605.

25. Kobayashi D, Kondo K, Uehara N, Otokozawa S, Tsuji N, Yagihashi A, et al. Endogenous reactive oxygen species is an important mediator of miconazole antifungal effect. Antimicrob Agents Chemother. 2002;46(10): 3113-7.

26. Ferreira GF, Baltazar LM, Santos JR, Monteiro AS, Fraga LA, Resende-Stoianoff MA, et al. The role of oxidative and nitrosative bursts caused by azoles and amphotericin B against the fungal pathogen Cryptococcus gattii. J Antimicrob Chemother. 2013;68(8):1801-11.

27. Pamp SJ, Gjermansen M, Johansen HK, Tolker-Nielsen T. Tolerance to the antimicrobial peptide colistin in Pseudomonas aeruginosa biofilms is linked to metabolically active cells, and depends on the pmr and mexAB-oprM genes. Mol Microbiol. 2008;68(1):223-40.

28. Zemke AC, Shiva S, Burns JL, Moskowitz SM, Pilewski JM, Gladwin MT, et al. Nitrite modulates bacterial antibiotic susceptibility and biofilm formation in association with airway epithelial cells. Free Radic Biol Med. 2014;77:307-16.

29. Deris ZZ, Akter J, Sivanesan S, Roberts KD, Thompson PE, Nation RL, et al. A secondary mode of action of polymyxins against gram-negative bacteria involves the inhibition of $\mathrm{NADH}$-quinone oxidoreductase activity. J Antibiot (Tokyo). 2014;67(2):147-51.

30. Deris ZZ, Swarbrick JD, Roberts KD, Azad MA, Akter J, Horne AS, et al. Probing the penetration of antimicrobial polymyxin lipopeptides into gramnegative bacteria. Bioconjug Chem. 2014;25(4):750-60.

31. Yeom J, Imlay JA, Park W. Iron homeostasis affects antibiotic-mediated cell death in Pseudomonas species. J Biol Chem. 2010;285(29):22689-95.

32. Yu Z, Qin W, Lin J, Fang S, Qiu J. Antibacterial mechanisms of polymyxin and bacterial resistance. Biomed Res Int. 2015;2015:679109.

33. Scandalios JG. Oxidative stress: molecular perception and transduction of signals triggering antioxidant gene defenses. Braz J Med Biol Res. 2005;38(7): 995-1014.

34. Zhang L, Dhillon P, Yan H, Farmer S, Hancock RE. Interactions of bacterial cationic peptide antibiotics with outer and cytoplasmic membranes of Pseudomonas aeruginosa. Antimicrob Agents Chemother. 2000;44(12):331721.

35. Velkov T, Soon RL, Chong PL, Huang JX, Cooper MA, Azad MA, et al. Molecular basis for the increased polymyxin susceptibility of Klebsiella pneumoniae strains with under-acylated lipid a. Innate Immun. 2013;19(3): 265-77.

36. Coats SR, To TT, Jain S, Braham PH, Darveau RP. Porphyromonas gingivalis resistance to polymyxin $B$ is determined by the lipid a 4'-phosphatase, PGN_0524. Int J Oral Sci. 2009;1(3):126-35.

37. Moskowitz SM, Ernst RK, Miller SI. PmrAB, a two-component regulatory system of Pseudomonas aeruginosa that modulates resistance to cationic antimicrobial peptides and addition of aminoarabinose to lipid a. J Bacteriol. 2004;186(2):575-9.

38. Lee H, Hsu FF, Turk J, Groisman EA. The PmrA-regulated pmrC gene mediates phosphoethanolamine modification of lipid a and polymyxin resistance in salmonella enterica. J Bacteriol. 2004;186(13):4124-33.

39. Tielen $\mathrm{P}$, Kuhn $\mathrm{H}$, Rosenau F, Jaeger KE, Flemming HC, Wingender J. Interaction between extracellular lipase LipA and the polysaccharide alginate of Pseudomonas aeruginosa. BMC Microbiol. 2013;13:159.

40. Batoni G, Maisetta G, Esin S. Antimicrobial peptides and their interaction with biofilms of medically relevant bacteria. Biochim Biophys Acta. 2016 1858(5):1044-60

41. Galvão SS, Monteiro AS, Siqueira EP, Bomfim MR, Dias-Souza MV, Ferreira GF, et al. Flavonoids act as antimicrobials by binding to. Front Microbiol. 2016;7: 2053.

42. Rodrigues A, Gomes A, Marçal PH, Dias-Souza MV. Dexamethasone abrogates the antimicrobial and antibiofilm activities of different drugs against clinical isolates of. J Adv Res. 2017;8(1):55-61.

43. Ferreira GF, Santos JR, Costa MC, Holanda RA, Denadai AM, Freitas GJ, et al. Heteroresistance to Itraconazole alters the morphology and increases the 
virulence of Cryptococcus gattii. Antimicrob Agents Chemother. 2015;59(8): 4600-9.

44. Ferreira GF, Dos Santos Pinto BL, Souza EB, Viana JL, Zagmignan A, Dos Santos JR, et al. Biophysical effects of a polymeric biosurfactant in Candida krusei and Candida albicans cells. Mycopathologia. 2016;181(11-12):799806

Ready to submit your research? Choose BMC and benefit from:

- fast, convenient online submission

- thorough peer review by experienced researchers in your field

- rapid publication on acceptance

- support for research data, including large and complex data types

- gold Open Access which fosters wider collaboration and increased citations

- maximum visibility for your research: over $100 \mathrm{M}$ website views per year

At $\mathrm{BMC}$, research is always in progress.

Learn more biomedcentral.com/submissions 